\title{
The influence of debris cover and glacial lakes on the recession of glaciers in Sikkim Himalaya, India
}

\author{
Smriti BASNETT, ${ }^{1}$ Anil V. KULKARNI, ${ }^{1}$ Tobias BOLCH ${ }^{2,3}$ \\ ${ }^{1}$ Divecha Centre for Climate Change, Indian Institute of Science, Bangalore, India \\ E-mail: smritibas@gmail.com \\ ${ }^{2}$ Department of Geography, University of Zürich, Zürich, Switzerland \\ ${ }^{3}$ Institute for Cartography, Technische Universität Dresden, Dresden, Germany
}

\begin{abstract}
We investigated area changes in glaciers covering an area of $\sim 200 \mathrm{~km}^{2}$ in the Tista basin, Sikkim, Eastern Indian Himalaya, between 1990 and 2010 using Landsat Thematic Mapper (TM) and Indian Remote-sensing Satellite (IRS) images and related the changes to debris cover, supraglacial lakes and moraine-dam lakes. The glaciers lost an area of $3.3 \pm 0.8 \%$ between 1989/90 and 2010. More detailed analysis revealed an area loss of $2.00 \pm 0.82,2.56 \pm 0.61$ and $2.28 \pm 2.01 \mathrm{~km}^{2}$ for the periods 1989-97, 1997-2004/05 and 2004-2009/10, respectively. This indicates an accelerated retreat of glaciers after 1997. On further analysis, we observed (1) the formation and expansion of supraglacial lakes on many debris-covered glaciers and (2) the merging of these lakes over time, leading to the development of large moraine-dam lakes. We also observed that debris-covered glaciers with lakes lose a greater area than debris-covered glaciers without lakes and debris-free glaciers. The climatic data for 24 years (1987-2011), measured at the Gangtok meteorological station (1812 $\mathrm{m}$ a.s.l.), showed that the region experienced a $1.0^{\circ} \mathrm{C}$ rise in the summer minimum temperature and a $2.0^{\circ} \mathrm{C}$ rise in the winter minimum temperature, indicating hotter summers and warmer winters. There was no significant trend in the total annual precipitation. We find that glacier retreat is caused mainly by a temperature increase and that debris-covered glaciers can retreat at a faster rate than debris-free glaciers, if associated with lakes.
\end{abstract}

\section{INTRODUCTION}

The glaciers of the Himalaya contribute to a varying degree to the overall river runoff in South Asia. The highest contribution is from the Indus River which originates in the northwest Himalaya (Immerzeel and others, 2010). The contribution of glacier meltwater to the overall runoff, which is higher in the upper reaches of the rivers (Kaser and others, 2010), constitutes the main water source for micro and mini hydroelectric projects, irrigation, and domestic and adventure tourism for different regions (Krishna, 2005). However, detailed information about the importance of glacier melt is still rare, though precise data about glacier area and volume, their changes over time and the causes of these changes exist. While glacier area changes have been comparatively well documented in the western Indian Himalaya (Kulkarni and others, 2011; Bolch and others, 2012), little information is available for the eastern Himalaya including the Sikkim Himalayan glaciers. Many glaciers in the Himalaya are covered with supraglacial debris that alters their response to climate change (Scherler and others, 2011; Bolch and others, 2012). While a thick debris cover is expected to reduce glacier retreat (Scherler and others, 2011), several recent studies have shown that debris-covered glaciers have lost significant mass in recent decades or are clearly retreating despite thick debris cover (Bolch and others, 2011; Kääb and others, 2012; Nuimura and others, 2012; Bhambri and others, 2013). This has been attributed to enhanced ice melt on glacial lakes and ice cliffs (Sakai and others, 2000; Bolch and others, 2012).

An extensive glacier inventory for Sikkim Himalaya using Indian Remote-sensing Satellite IRS-1C/1D LISS III (Linear Imaging Self-Scanning sensor III) data of 1 January 1997 mapped 84 glaciers occupying an area of $440.30 \mathrm{~km}^{2}$ and estimated a volume of $140 \mathrm{~km}^{3}$ (Bahuguna and others,
2001). For the volume estimate, the area-volume scaling method suggested by Meier (1961) and UNESCO/International Association of Scientific Hydrology (1970) was adopted. In the inventory, the majority of glaciers were smaller than $5 \mathrm{~km}^{2}$ and only two were larger than $20 \mathrm{~km}^{2}$. The average altitude of the snowline was $\sim 6000 \mathrm{~m}$ a.s.l. in January 1990. The Sikkim glaciers comprise valley glaciers with elevations ranging from $\sim 3720$ to $\sim 8400$ ma.s.I. In addition, permanent snowfields covering an area of $251.22 \mathrm{~km}^{2}$ were mapped (Bahuguna and others, 2001). Many glaciers in Sikkim are covered by debris. The largest and most well-known glacier of Sikkim is Zemu Glacier (Raina and others, 1973) which is situated below Mount Kanchenjunga (8586 m a.s.l.) and was first mapped during an expedition of German researchers (Finsterwalder, 1935). Changme Khangpu, one of the Sikkim glaciers, has been studied using Si-32 and Pb-210 chronology, and the results showed (1) a retreat rate of $6 \mathrm{~m} \mathrm{a}^{-1}$ between 1976 and 1981, (2) an accumulation rate of $0.7 \mathrm{~m} \mathrm{a}^{-1}$, and (3) a basal flow of $0.01 \mathrm{~m} \mathrm{a}^{-1}$ compared to a surface flow of $40 \mathrm{~m} \mathrm{a}^{-1}$, indicating that the deeper ice near the bedrock travels much more slowly than the surface ice (Shukla and others, 1983; Nijampurkar, 1985; Nijampurkar and others, 1985). Another study estimated the average rate of glacier retreat as $13 \mathrm{~m} \mathrm{a}^{-1}$, for 26 glaciers in Sikkim, using satellite images between 1976 and 2005 (Raina, 2009). Snow studies using the normalized difference snow index (NDSI) method showed a maximum snow-cover extent of $50 \%$ in February, with accumulation peaks in October and February. The snow extent was comparatively high (35-40\%) even in the summer months, indicating different snow accumulation and ablation patterns in Sikkim as compared to the western Himalaya (Basnett and others, 2011). However, there is still very little information on glacier changes in Sikkim. The 


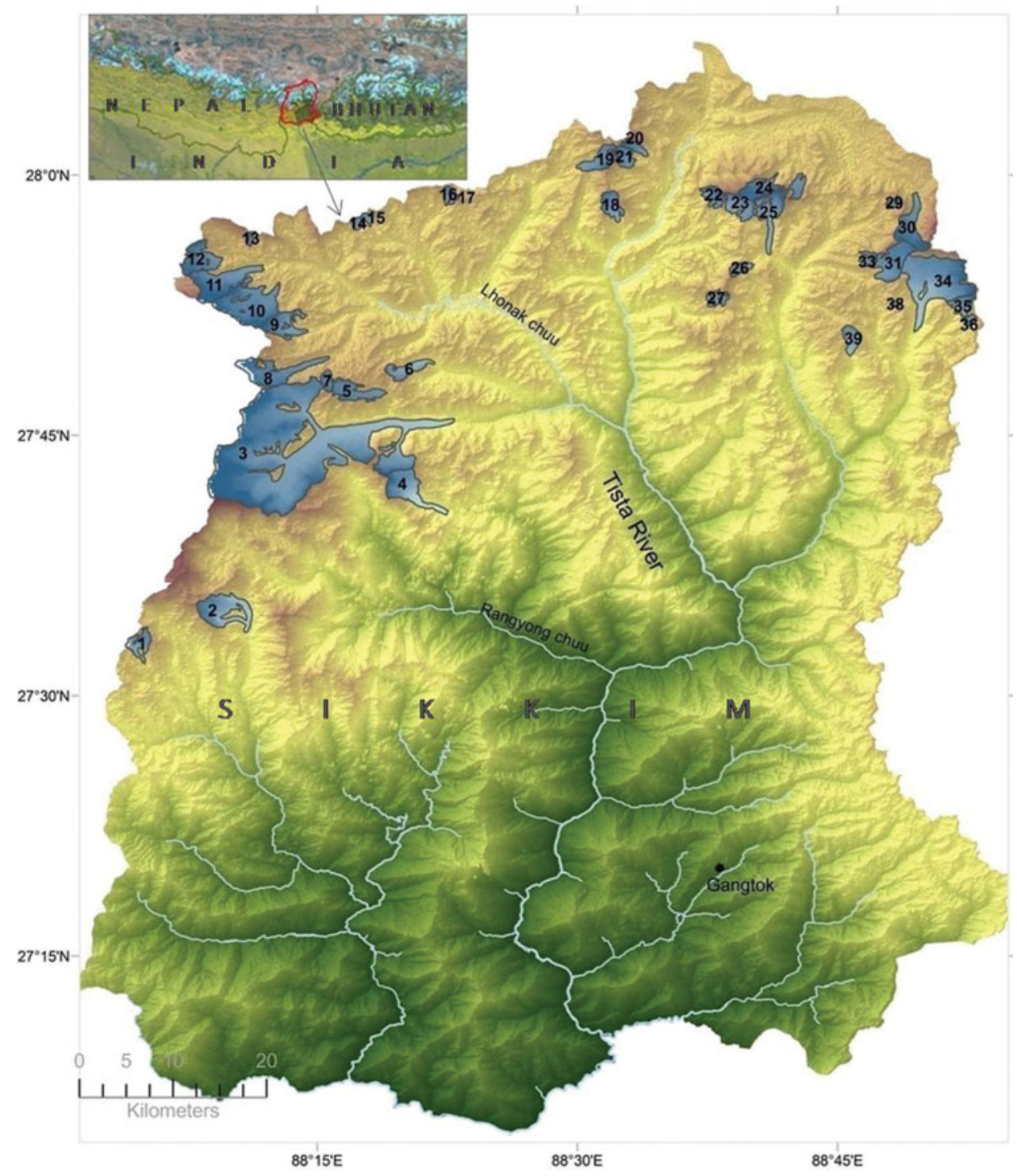

Fig. 1. Location map of Sikkim. The region is located between Nepal and Bhutan. The map shows locations of glaciers in the Tista basin, Sikkim. The meteorological data of Gangtok were analysed.

remote and rugged terrain of Sikkim Himalaya and the politically restricted boundaries inhibit the study of massbalance and glacier fluctuations. In addition, supraglacial and moraine-dammed lakes, which are common in Sikkim (Raj and others 2012), influence glacier changes.

The aims of this paper are therefore (1) to present a detailed and long-term analysis of glacier area changes in Sikkim Himalaya, and (2) to understand the influence of debris cover and moraine-dam lakes on glacier retreat.

\section{STUDY AREA}

We focus on Sikkim Himalaya where many debris-covered glaciers are present. Sikkim is a part of the Eastern Indian Himalayan ranges and lies between Nepal and Bhutan (Fig. 1). It is a mountainous state of India, extending $\sim 114 \mathrm{~km}$ from north to south and $64 \mathrm{~km}$ from east to west, with a total geographical area of $7096 \mathrm{~km}^{2}$. The state is situated between $27^{\circ} 00^{\prime} 46^{\prime \prime}$ and $28^{\circ} 07^{\prime} 48^{\prime \prime} \mathrm{N}$ and $88^{\circ} 00^{\prime} 58^{\prime \prime}$ and $88^{\circ} 55^{\prime} 25^{\prime \prime} \mathrm{E}$. The mountainous topography ranges from 300 to $8598 \mathrm{~m}$ a.s.l., covering subtropical to alpine ecozones, within a short horizontal distance. The state receives an annual precipitation of 2000-4000 mm (http://www.sikkimipr.org), while the Asian monsoon contributes $>80 \%$ of precipitation during the summer months (Bookhagen and Burbank, 2010). Most of the geographical area of Sikkim is drained by the Tista River, a tributary of the Brahmaputra River.

\section{DATA AND METHODS}

\section{Data sources}

Landsat Thematic Mapper (TM) (Level 1T) and Indian Remote-sensing Satellite (IRS) LISS III satellite images were analysed to map and monitor the glacier changes (Tables 1 and 2). The LISS III images were co-registered to the Landsat images and used for delineating glacier boundaries. In addition, the Landsat TM (Level 1T) and topographic maps of the Survey of India were used as reference data. The Landsat images were downloaded from the US Geological Survey (USGS) website (http://glovis.usgs.gov/), and the topographic map was acquired from the Sikkim State Council of Science and Technology and the Department of Mines, Minerals and Geology, Government of Sikkim. The glacier extents from the topographic maps, surveyed in 1962/63 and 1966/67, 
Table 1. Satellite and sensor characteristics



Source: http://landsat.usgs.gov/Satellite_and_Sensor_Information.php and http://www.isro.org/satellites/earthobservationsatellites.aspx

indicate a general recession. However, we did not use these outlines for a quantitative assessment, as glacier boundaries on the topographic maps are uncertain due to errors in the identification of debris-covered glacier tongues and snowfields (Bhambri and Bolch, 2009).

In the western Himalaya where the summer monsoon is of less influence than in the east, the glaciers are usually mapped using satellite images of the July-September season, as the seasonal snow cover is at a minimum and the glaciers are fully exposed (Kulkarni, 1991). However, in Sikkim, in the eastern Himalaya where little precipitation occurs during winter, images from November-December and January have been selected based on minimal seasonal snow and cloud cover (Basnett and Kulkarni, 2012). The images were supplemented with the data of the March and October season. In addition, multi-date scenes for the same year were used to overcome issues related to shadows.

\section{Glacier mapping and analysis}

We manually delineated the glaciers and moraine-dam lakes using false-colour composites with band combinations of red, near-infrared (NIR) and shortwave infrared (SWIR), and a true-colour composite of red, green and NIR, of Landsat TM/ETM+ and LISS III images. We also used contrast techniques such as brightness and linear stretching, and a shaded relief map derived from the Shuttle Radar Topography Mission digital elevation model (SRTM DEM) (90 m; http://vterrain.org/Elevation/SRTM/) to aid the manual interpretation of glacial features. In addition, we referred the Survey of India maps for the identification, location and interpretation of glaciers on satellite images. We also used the NDSI $($ NDSI $=($ green - SWIR $) /($ green + SWIR $))$ applied on an Advanced Wide Field Sensor (AWiFS) image of the years 2004 and 2005 to eliminate non-glacier areas under mountain shadow conditions (cf. Kulkarni and others, 2006). Glacier boundaries in the accumulation area were demarcated by 'ice divides', which were visually detected and manually digitized based on the shaded relief map.

The glacier area was determined for four different periods: 1989/90, 1997, 2004 and 2009/10. The 1990 glacier boundary was used as a 'master inventory' because of good image quality. As the oldest data layer, it was used to estimate glacier retreat for the following years. The changes were estimated only in the lower region, as very little or no change was observed in the upper regions. Moreover, since the upper regions including the accumulation area were generally snow-covered on the available images, it was difficult to identify small changes in those areas.

\section{Estimation of uncertainties}

Estimating the uncertainty is crucial to assess the significance of the results and to avoid misinterpretation. The accuracy of the outlines depends, typically, on the resolution of the images used, the conditions during image acquisition (seasonal snow, shadow) and the contrast between the glacier and its surroundings (DeBeer and Sharp, 2007). The latter is especially low for debris-covered glaciers. The most accurate way to assess glacier outlines would be highresolution imagery (Paul and others, 2013). However, such data were, as in most studies in remote mountainous areas, not available for our study region. A widely used and recommended approach is to estimate the uncertainty using a buffer of up to one pixel size to the glacier margin (Granshaw and Fountain, 2006; Bolch and others, 2010; Paul and others, 2013). In this study, uncertainties in the estimation of 'glacier extent' and 'retreat' were considered due to (1) the spatial resolution of satellite data and (2) the lack of a distinct difference between glacial and non-glacial areas caused by a debris cover. These are called 'Mapping'

Table 2. List of satellite data used in the investigation

\begin{tabular}{cccc}
\hline Year & $\begin{array}{c}\text { Landsat TM } \\
\text { (path 139 row 41) }\end{array}$ & $\begin{array}{c}\text { Landsat ETM+ } \\
\text { (path 139 row 41) }\end{array}$ & $\begin{array}{c}\text { IRS LISS III } \\
\text { (path 107 row 52 ) }\end{array}$ \\
\hline 1989 & 25 October & & \\
1990 & 13 January & & 1 January \\
1997 & & & \\
2004 & & & \\
2005 & 14 November & 24 December & \\
2009 & 9 November & 1 November & \\
2010 & 28 January, & 4 November & \\
& 25 November &
\end{tabular}




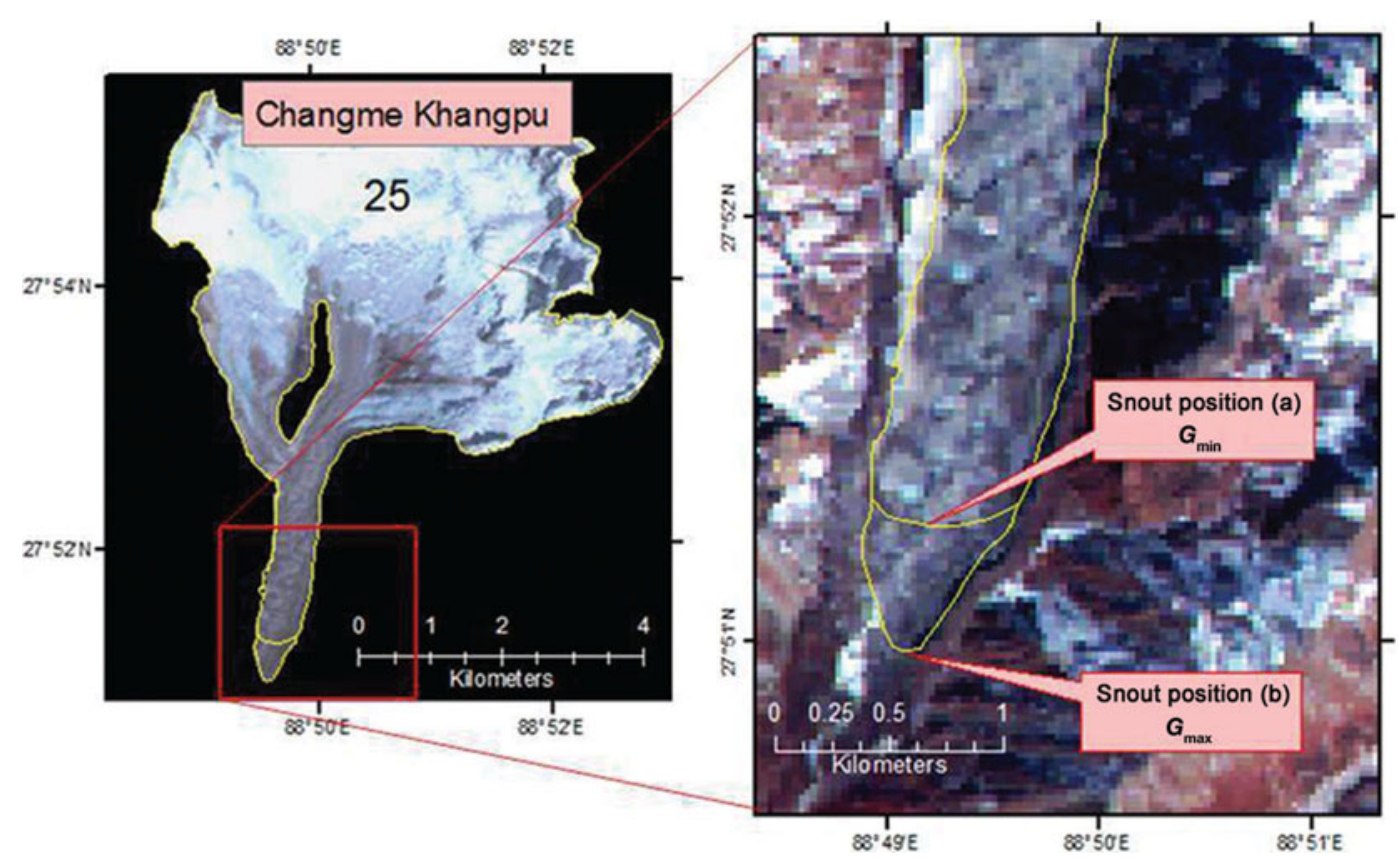

Fig. 2. The identification of a glacier terminus can sometimes be difficult using satellite imagery, if glaciers are covered by debris. In this study, alternative snout positions have been estimated using a 'visual interpretation technique', based on tone, texture and colour. This image shows a true-colour composite with a band combination of green, red and NIR. Two extreme positions were identified at (a) ' $\mathrm{G}_{\max }$ ' and (b) ' $\mathrm{G}_{\text {min }}$ ' snout positions. This was used to estimate uncertainty in the interpretation. A satellite image of LISS III, IRS-P6, 25 March 2004, path 107 row 52, is shown.

and 'Interpretation' uncertainties. We estimate the mapping uncertainty as

$$
\text { Mapping uncertainty }(\mathrm{a})=\mathrm{N} \times \frac{\mathrm{A}}{2}
$$

where $N$ is the number of pixels along the glacier boundary and $A$ is the area of the pixel.

The interpretation uncertainty was estimated manually by mapping possible alternative glacier boundaries (Fig. 2). This technique was applied for the first time while interpreting glacier boundaries around the snout, especially for debriscovered glaciers. Alternative snout positions were estimated using a visual interpretation technique, based on shape, size, pattern, tone, texture and association (Kulkarni, 1991). Two extreme positions were identified at (a) ' $G_{\max }$ ' and (b) ' $G_{\min }$ ' snout positions as shown in Figure 2. These were used to estimate uncertainty in the interpretation:

$$
\text { Interpretation uncertainty }(\mathrm{b})=G_{\max }-G_{\min }
$$

where $G_{\max }$ is the maximum possible glacier extent and $G_{\min }$ is the minimum possible glacier extent.

$$
\text { Total uncertainty }=\sqrt{a^{2}+b^{2}}
$$

However, the uncertainty of glacier shrinkage is likely to be overestimated when calculating uncertainty based on the method mentioned above, because, for each time period, the vast majority of the area changes are usually restricted to the snout. Hence, to estimate uncertainties in area changes between two time periods, the changes in the areal extent near the snout are considered. These uncertainties in glacier area changes can be written as

$$
\begin{array}{r}
\text { Uncertainty in glacier change }=N_{S} \times A+(\text { interpretation } \\
\text { uncertainty })
\end{array}
$$

where $N_{S}$ is the number of pixels along the boundary of the snout where changes occurred.

\section{RESULTS}

\section{Glacier area in Sikkim}

In this study, 39 glaciers were mapped and monitored, to estimate the loss in glacier area (Fig. 1). Though the Sikkim glacier inventory by Bahuguna and others (2001) mapped 84 glaciers covering $440.31 \mathrm{~km}^{2}$, in this study not all the glaciers could be mapped due to a cloud and snow cover. Nevertheless, the 39 glaciers mapped occupy an area of $333.0 \pm 9.1 \mathrm{~km}^{2}$ in $1989 / 90$, which represents $\sim 75 \%$ of the glacierized area in the Tista basin. The overall loss in glacier area in 20 years, from 1989/90 to 2009/10, was $6.9 \pm 1.5 \mathrm{~km}^{2}$ ( 2\%). Zemu Glacier (Fig. 1, glacier No. 3) covered 37\% $\left(\sim 131 \mathrm{~km}^{2}\right)$ of the investigated glacier area and showed no significant change of the terminus in the 1990, 1997, 2004 and 2010 images. This is possibly due to its large size, steep slope, glacier dynamics and thick debris cover at the tongue (Venkatesh and others, 2011). Zemu Glacier was not included in the change analysis, in order to understand the fluctuations of small and medium-sized glaciers. The remaining 38 glaciers covered $201.9 \pm 7.0 \mathrm{~km}^{2}$ in 1989/90 and showed an overall loss of $6.9 \pm 1.5 \mathrm{~km}^{2}$ ( 3\%) until 2010 $\left(\sim 0.33 \mathrm{~km}^{2} \mathrm{a}^{-1}\right)$. The rate of change was $-0.16 \pm 0.10 \% \mathrm{a}^{-1}$ from 1990 to 2010, with an increasing rate after 1997 (Tables 3 and 4).

A good correlation $\left(r^{2}=0.25\right)$ was observed between glacier size and the relative area loss for debris-free glaciers, indicating a lower loss for large glaciers. However, the inclusion of debris-covered glaciers weakened the correlation $\left(r^{2}=0.10\right)$ between the size and area loss (Fig. 3), suggesting a strong influence of debris on the glacier retreat. Therefore, we carried out a more detailed analysis for debrisfree glaciers ('clean'), debris-covered glaciers without lakes ('debris'), and debris-covered glaciers with moraine-dammed lakes ('debris with lakes') to estimate the influences of these parameters on glacier retreat. 




Fig. 3. The influence of glacial size on retreat for debris-covered and clean glaciers (debris-free) between 1989 and 2010. The clean glaciers show a high loss in glacier area for small-sized glaciers, but the debris-covered glaciers show variable retreat and are independent of glacier size.

\section{Glacier comparison: 'clean', 'debris' and 'debris with lakes'}

In 1989/90, 12 out of 38 glaciers had no debris cover ('clean'), 12 were covered by supraglacial debris ('debris'), while 14 were debris-covered and associated with morainedam lakes ('debris with lakes'). Between 1989/90 and 2010, we observed (1) an increase in the area of debris cover by $6.5 \pm 1.4 \mathrm{~km}^{2}$ and (2) the formation and expansion of supraglacial lakes on two glaciers (Fig. 4c-f). These lakes joined and developed moraine-dam lakes on two debriscovered glaciers (Fig. 5), indicating a transformation in the characteristics of the glaciers, as debris cover has promoted the development of lakes. These moraine-dam lakes developed at the glacier termini at certain altitudes $(\sim 6300 \mathrm{~m}$ a.s.l.) on the medium-sized 'debris-covered glaciers' (Fig. 4f). A field photograph showing moraine-dam lakes at the terminus of Tista Khangse Glacier (No. 30 in Fig. 1) is shown in Figure 6.

Table 3. Total glacier area for 38 glaciers in the Tista basin

\begin{tabular}{lcc}
\hline Year & $\begin{array}{c}\text { Total glacier area } \\
\mathrm{km}^{2}\end{array}$ & $\begin{array}{c}\text { Total uncertainty } \\
\mathrm{km}^{2}\end{array}$ \\
\hline $1989 / 90$ & 201.91 & \pm 7.09 \\
1997 & 199.91 & \pm 6.64 \\
$2004 / 05$ & 197.41 & \pm 6.51 \\
$2009 / 10$ & 195.31 & \pm 7.13 \\
\hline
\end{tabular}

\section{Glacier area changes}

We observed a large difference in the area changes of (1) clean (mean size $3.2 \mathrm{~km}^{2}$ ), (2) debris (mean size $6 \mathrm{~km}^{2}$ ) and (3) debris-covered glaciers with lakes (mean size $6.4 \mathrm{~km}^{2}$ ) between 1989/90 and 2009/10. The 12 'clean' glaciers lost $5.3 \pm 1.0 \%$ of their area, the 10 'debris-covered glaciers' lost $3.9 \pm 1.3 \%$, and the 16 'debris with lakes' lost $9.0 \pm 1.4 \%$ (Fig. 7). Hence, glaciers with 'debris' appear to shrink at a lower rate than 'debris-free' glaciers, but the 'debris with lakes' glaciers lose area at a much higher rate. This is about 1.7 times higher than 'clean' and 2.3 times higher than 'debris-covered glaciers', suggesting that the debris cover retards melting while the presence of lakes on debris-covered glaciers accelerates glacier retreat (Fig. 7).

\section{Altitude zone analysis}

The 38 glaciers in this study ranged from $\sim 4200$ to $\sim 7600 \mathrm{~m}$, with an average altitude of $\sim 5780 \mathrm{~m}$. The mean altitude was (1) $5783 \mathrm{~m}$ for 'clean', (2) $5610 \mathrm{~m}$ for 'debris-covered' and (3) $5825 \mathrm{~m}$ for 'debris with lakes' glaciers. The altitude distribution pattern (Fig. 8) showed that despite similar glacier altitudes of 'clean' and 'debris with lakes', the 'debris with lakes' glaciers lost area at a higher rate (Fig. 7), indicating an accelerated retreat of debris-covered glaciers when associated with lakes. We also observed a large difference in the altitude location of glaciers with 'debris' versus 'debris with lakes'. The glaciers with 'debris' are located $\sim 200 \mathrm{~m}$ lower than 'debris with lakes' glaciers (Fig. 9), but showed a three times lower retreat (Fig. 7). This indicates that the presence of a water body influences and accelerates melting, while altitudinal differences have a clearly lower influence. Moreover, though the mean size of

Table 4. Area loss for 38 glaciers in the Tista basin

\begin{tabular}{lccc}
\hline & $(1989 / 90)-1997$ & (2004/05)-2010 & $(1989 / 90)-(2009 / 10)$ \\
\hline Area loss $\left(\mathrm{km}^{2}\right)$ & $2.00 \pm 0.82$ & $2.56 \pm 0.61$ & $2.28 \pm 2.01$ \\
Annual area loss $\left(\mathrm{km}^{2} \mathrm{a}^{-1}\right)$ & $0.27 \pm 0.11$ & $0.34 \pm 0.08$ & $0.46 \pm 0.40$ \\
Area loss $(\%)$ & $0.99 \pm 0.41$ & $1.24 \pm 0.30$ & $1.04 \pm 1.02$ \\
Annual area loss $\left(\% \mathrm{a}^{-1}\right)$ & $0.13 \pm 0.05$ & $0.17 \pm 0.04$ & $0.21 \pm 0.14$ \\
& & & $0.16 \pm 0.07 \pm 0.77$ \\
\hline
\end{tabular}



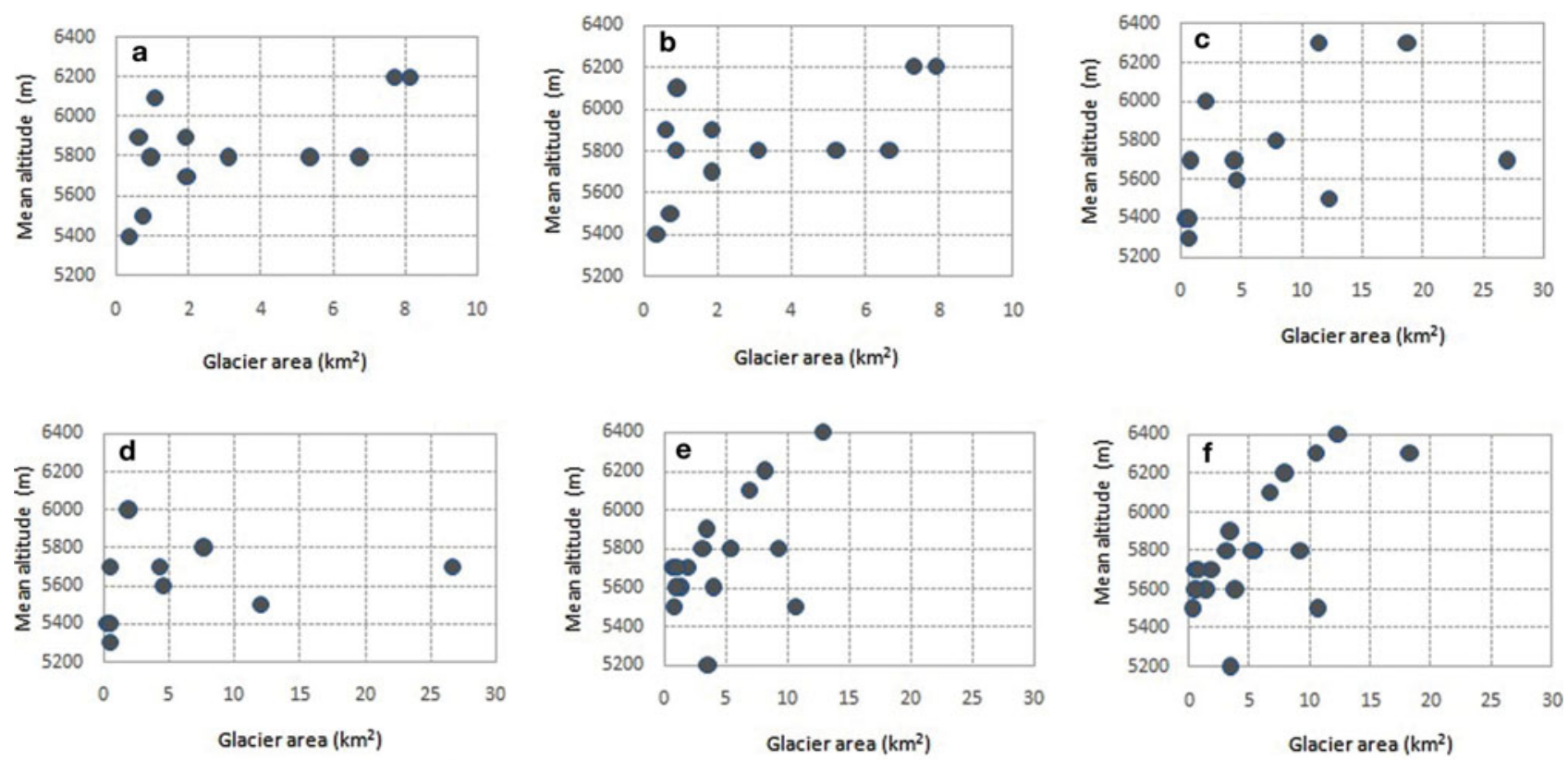

Fig. 4. The distribution and number of 'clean', 'debris' and 'debris with lakes' glaciers: (a) 'clean' glaciers (1990) ( $n=12)$; (b) 'clean' glaciers (2010) ( $n=12)$; (c) 'debris-covered glaciers without lakes' (1990) $(n=10)$; (d) 'debris-covered glaciers without lakes' (2010) ( $n=10)$; (e) 'debris-covered glaciers with lakes' (1990) ( $n=14)$; (f) 'debris-covered glaciers without lakes' $(2010)(n=16)$. ( $f$ ) shows an increase in the number of lakes on debris-covered glaciers over 20 years, between 1990 and 2010.
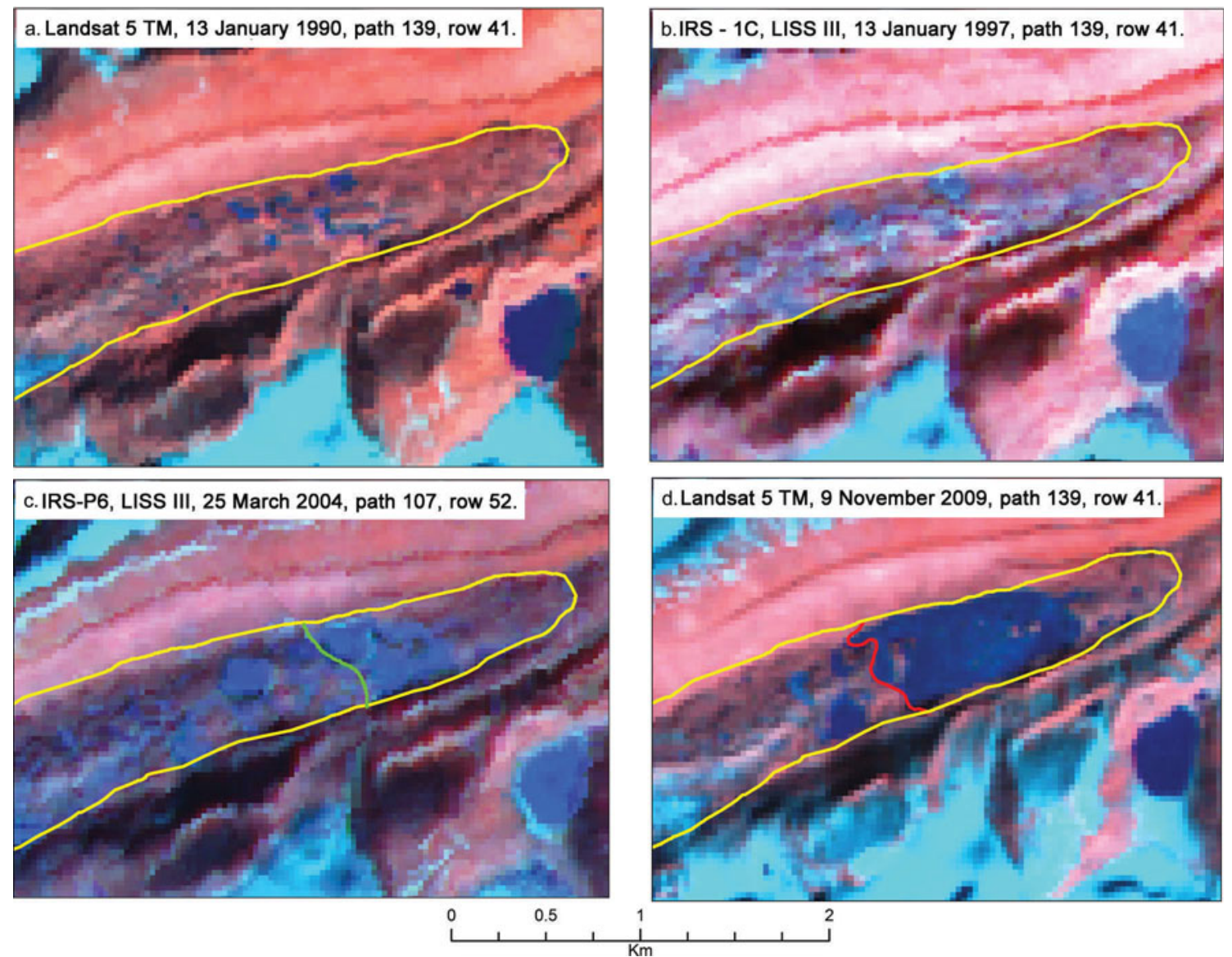

Fig. 5. Evolution and coalescence of a supraglacial lake and the formation of a moraine dam: (a, b) show no frontal change between 1990 and 1997; (b) shows the evolution of a supraglacial lake and (c) the coalescence of a supraglacial lake, which occupies glacier area between two lateral moraines; and (d) shows the formation of a moraine dam lake leading to glacier area loss. The four images used are a false-colour composite with a band combination of red, NIR and SWIR. 




Fig. 6. Moraine-dam lake (Khangchung $\mathrm{Chho}$ ) at the terminus of Tista Khangse Glacier (No. 30 in Fig. 1).

'debris' glaciers and 'debris with lakes' was comparatively similar, a higher area loss was observed on 'debris with lakes' glaciers, suggesting the influence of lakes on glacier retreat.

\section{Lake area changes}

In 2010, 16 lakes were associated with debris-covered glaciers, and 7 were associated with debris-free glaciers. The 16 debris-covered glaciers and the 7 debris-free glaciers associated with lakes both showed a two times higher loss in glacier area than the glaciers without lakes. Thus, of the
38 glaciers studied in this investigation, moraine-dam lakes were associated with 23 and these glaciers showed a five times greater loss in glacier area, suggesting the influence of lakes on glacier retreat (Fig. 8). The areal extent of the individual lakes ranged between 0.04 and $2.10 \mathrm{~km}^{2}$, and the overall lake area increased from $6.6 \pm 0.8 \mathrm{~km}^{2}$ to $9.6 \pm 1.1 \mathrm{~km}^{2}$, between 1990 and 2010 . This increase in area was due to the expansion of moraine-dammed lakes, but also to the formation and coalescence of supraglacial lakes on two debris-covered glaciers. An example of lake expansion, near the terminus of South Lhonak Glacier (glacier No. 11 in Fig. 1), is shown in Figure 10.

\section{DISCUSSION}

\section{Influence of glacier size on glacier retreat}

In this study, the relationship between the glacier size and the area loss was strong for 'clean' glaciers. These glaciers showed a higher loss in glacial area for smaller glaciers in comparison with larger ones, which is consistent with the results in many other mountain regions in the Himalaya (e.g. the Baspa River and the Bhagirati and Alknanda River basins (Kulkarni and Alex, 2003; Bhambri and others, 2011)) and elsewhere in the world (e.g. Paul and others, 2004; Bolch and others, 2010). However, the correlation between size and loss in area was weak for debris-covered glaciers and even weaker for 'debris with lakes' glaciers, indicating a different reaction for the latter. Moreover, the loss in area for

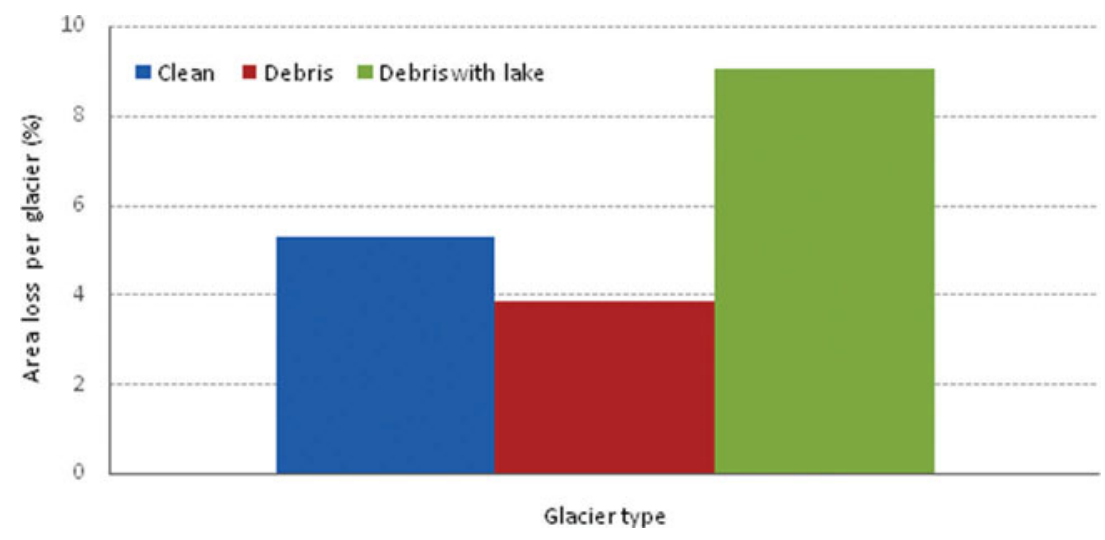

Fig. 7. The influence of debris-covered and moraine-dam lakes on glacier retreat. The numbers of glaciers used to estimate the percentage loss in area are 12, 10 and 16 for 'clean', 'debris' and 'debris with lakes', respectively. The figure suggests that debris cover can retard retreat. However, debris cover can also lead to the formation of lakes on moraines and this can accelerate retreat.

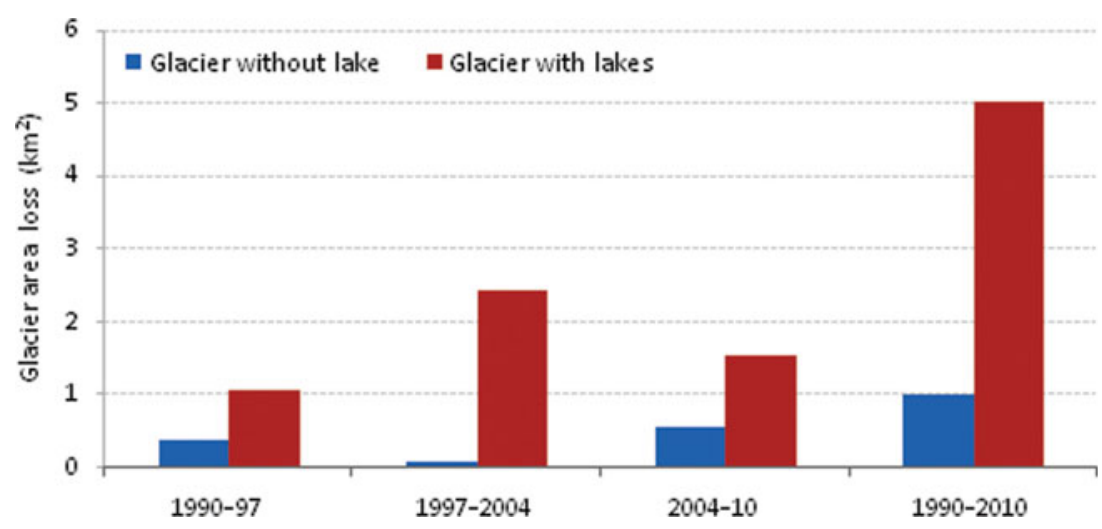

Fig. 8. The glaciers associated with lakes showed a higher loss in glacier area for all three observational periods, suggesting the influence of lakes on glacier retreat. 




Fig. 9. Area-altitude distribution of glaciers in Sikkim. The 'debris-covered glaciers with lakes' are distributed at higher altitudes than 'debriscovered glaciers without lakes'. The 'clean' and 'debris-covered glaciers with lakes' are distributed almost equally in the higher regions.

the 'debris with lakes' glaciers was twice as high as for the 'debris' glaciers (Fig. 7), though they were located almost at the same altitude (Fig. 9) and were of similar size $\left(\sim 6 \mathrm{~km}^{2}\right)$. This suggests that glacier retreat is affected much more by the presence of a water body on debris-covered glaciers than by altitude. Therefore, in the following subsections, detailed discussions are carried out to understand the influence of debris cover and lakes on glacier retreat.

\section{Influence of debris cover and glacial lakes on glacier variations}

Thick debris cover on glaciers leads, in general, to less frontal retreat or even stable tongues, as it lowers the rate of surface melting, as in Zemu Glacier and many other glaciers in the Himalaya (Tangborn and Rana, 2000; Bolch and others, 2008; Nainwal and others, 2008; Racoviteanu and

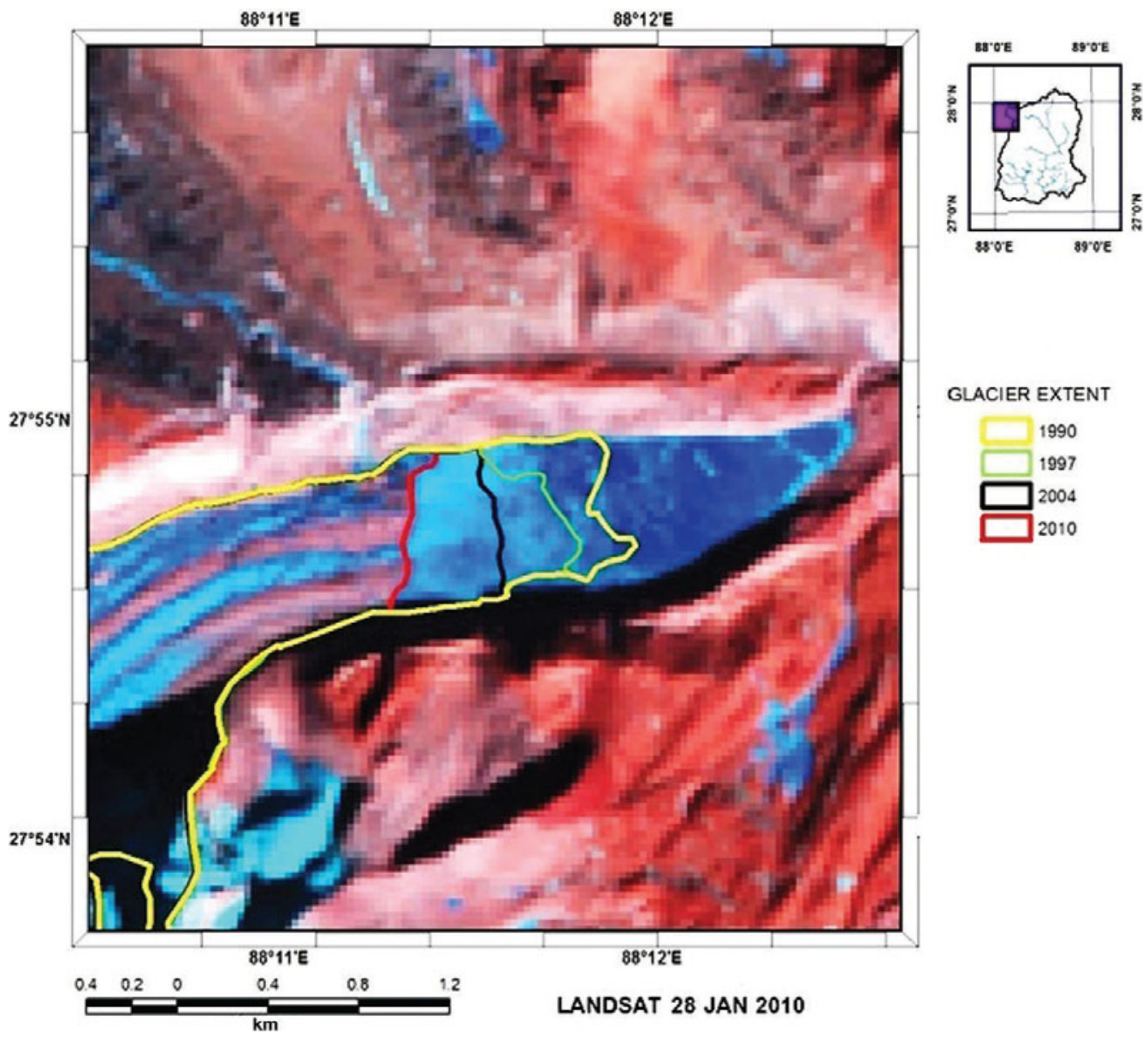

Fig. 10. The moraine-dammed lake at the terminus of South Lhonak Glacier (glacier No. 11 in Fig. 1) has expanded from $0.50 \pm 0.05 \mathrm{~km}^{2}$ to $1.08 \pm 0.07 \mathrm{~km}^{2}$ between 1990 and 2010. The expansion of the lake has reduced the glacier area by $4.39 \pm 0.71 \%$. 
others, 2008a,b; Bhambri and others, 2011; Scherler and others, 2011). However, this study suggests that debriscovered glaciers can have a large area loss despite a thick debris cover, if associated with lakes. This fact is important for Sikkim Himalaya as the majority of debris-covered glaciers in this region have moraine-dam lakes (Fig. 4f). Initially, as observed in this study, some debris-covered glaciers had stagnant fronts (Fig. 5), but over a period of time, lakes developed (1) near the terminus and (2) on the middle regions of the glacier tongues. These lakes, when formed at the terminus, merged and developed into moraine-dam lakes. In addition, the supraglacial lakes formed on the interiors of the glacier tongues, united and extended their area onto the lateral margins of the glaciers. When the boundaries of the lakes touch the lateral boundaries of the glacier, they cease to be a part of the glacier. The ice beyond the lake then becomes inactive and is separated from the glacier, leading to a loss in glacier area. This phenomenon was well observed in Changsang Glacier (17.9\% debris-covered; Fig. 5), where between 1990 and 1997 a supraglacial lake was part of the glacier. After 2004, however, it was no longer part of the glacier area, as the lake periphery collided with the lateral boundaries of the glacier, resulting in a loss of glacial area, caused by the formation of lakes and dead ice mounds. Once a stable lake is formed, it leads to the transfer of latent heat flux at the interface of water and ice (Sakai and others, 2000). In addition, a lake can absorb more solar radiation due to the lower albedo of water. These energy exchange processes cause the melting of ice below the lake water and finally its disappearance, if the lake is large and stable over a long period. This situation was also observed at several other debris-covered glaciers in the Himalaya and described for Imja Lake in the Mount Everest region (Fujita and others, 2009; Watanabe and others, 2009).

An increase in area of the debris cover on glaciers has also been detected elsewhere in the Himalaya (Bolch and others, 2008; Bhambri and others, 2011; Kamp and others 2011), indicating increased debris production, which reduces glacier transport capacity and leads to negative mass balances (Benn and others, 2012; Bolch and others, 2012).

Debris cover can cause differential rates of melting. Near the terminus, a thick debris cover retards melting, but at the upper reaches of the glacier tongue the thinner debris cover causes higher rates of melting. This causes a lessening, or even reversal, of the surface gradient (cf. Bolch and others 2011; Benn and others 2012) and leads to the formation of supraglacial lakes (Bennett and Glasser, 2009). These lakes then become prone to glacier melt (Sakai and Fujita, 2010; Benn and others, 2012). They may be temporary and drain if they reach the englacial drainage system ('perched lakes'; Gulley and Benn, 2007; Benn and others, 2012). However, if the lakes reach the base level, individual lakes join together and form a larger lake which can be dammed behind the terminal moraine ('base-level lakes'), as observed, for example, at Jonsung Glacier, Sikkim (glacier 10 in Fig. 1).

\section{Impact of lake formation}

Moraine-dam lakes have a strong impact on glacier dynamics. The lakes at the terminus of glaciers modify the stress regime of the glacier ice in contact. The presence of the lakes increases the terminus disintegration by the process of calving, and also transmits thermal energy to the ice front, accelerating melting which leads to a loss in glacier area (Komori, 2008; Röhl, 2008; Sakai and others, 2009; Gardelle and others, 2011). Detailed investigations in the Mount Everest area show a significant larger retreat and volume loss for debris-covered Imja Glacier, where a lake developed after the 1960s. This was not true for adjacent glaciers with similar characteristics but without any, or with very small, glacier lakes (Bajracharja and Mool, 2009; Bolch and others, 2011). This is observed in this study where moraine-dam lakes have substantially influenced glacier retreat, with an overall deglaciation of $0.20 \mathrm{~km}^{2}$ per glacier, between 1989 and 2010. Likewise, in the Himalaya, studies have reported a much larger lake growth in the eastern Himalaya than in the central and drier northwest regions (Xin and others, 2008; Gardelle and others, 2011).

\section{Climate considerations}

The mean annual air temperature (MAAT) record at Gangtok station (located at 1812 ma.s.I. (Fig. 1); has 24 years of continuous and complete long-term records) showed a rise of $1.03^{\circ} \mathrm{C}\left(0.043^{\circ} \mathrm{Ca}^{-1}\right)$ between 1987 and 2011. The summer (April-October) minimum temperature also recorded a rise of $\sim 1^{\circ} \mathrm{C}$, but a significant increase of $2.04^{\circ} \mathrm{C}$ was observed in the winter (November-March) minimum temperature. The winter maximum temperature rose by $1.13^{\circ} \mathrm{C}$ as opposed to a $0.17^{\circ} \mathrm{C}$ rise in the summer maximum temperature, suggesting warmer winters (Fig. 11). The precipitation had no clear trend due to the high variability in rainfall patterns, but, on average, there was a slight decrease in winter precipitation (Fig. 12).

The climate observations showed a rise in MAAT and a decline in the winter precipitation. These observations are similar to weather station data observed in Nepal Himalaya (Shrestha and others, 2000). The Sikkim glaciers are predominantly monsoon-affected and are more sensitive to temperature changes than winter-accumulation-type glaciers, as the temperature increase directly reduces solid precipitation (Fujita, 2008). One reason for the loss in glacier area and the development of lakes on the Sikkim glaciers could be the rise in MAAT over recent decades and, especially, higher winter and summer minimum temperatures, leading to a prolonged melting season, accompanied by a slight decrease in winter precipitation (Figs 11 and 12). Precipitation may fall as rain on the higher regions of glaciers and reduce the accumulation area, leading to an upward shift in the $0^{\circ} \mathrm{C}$ isotherm line. This causes a high rate of retreat at lower elevations (Racoviteanu and others, 2008b; Bolch and others, 2012).

However, the climate record is too short-term for confirmation, as the glacier response time, which can be some decades for larger glaciers, has to be taken into account. In addition, Gangtok station and most of the regional weather stations are located below $2000 \mathrm{~m}$ in Sikkim and may not provide applicable comparisons to the glacier environment. This is especially true for precipitation, which is highly variable, especially in mountainous terrain, so trends can differ significantly (Bhambri and others, 2011). Thus, setting up a glacier observatory would fill the data gap.

\section{CONCLUSIONS}

Remote-sensing data were used to estimate the glacier area in the Tista basin for the years 1989/90, 1997, 2004/05 and 2009/10. The 'mapping' and 'interpretation' uncertainties 

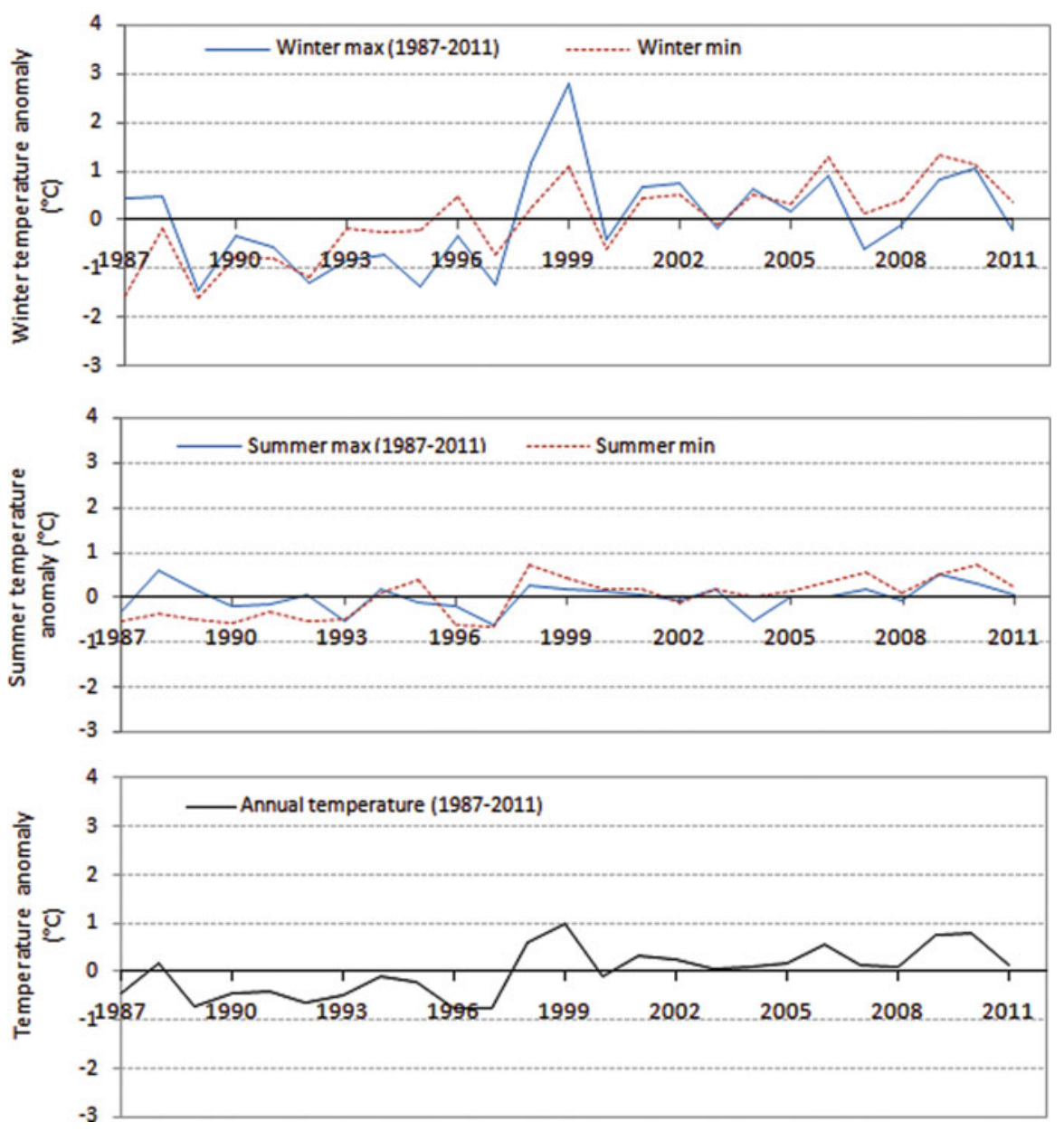

Fig. 11. Trends in mean annual, summer and winter temperatures from 1987 to 2011 at Gangtok, Sikkim. The summer months are AprilOctober and the winter months are November-March. The temperature trends are extracted from the mean monthly temperature records at Gangtok station.

were estimated using perimeters, spatial resolution of sensors and considering uncertainties in identifying glacier snouts. The investigation has shown an overall reduction of $6.9 \pm 1.5 \mathrm{~km}^{2}\left(\sim 0.16 \% \mathrm{a}^{-1}\right)$ in the glacier area between 1989 and 2010. The loss in glacier area in Sikkim accelerated after 1997. Moreover, the development and expansion of lakes and supraglacial lakes on debris-covered glaciers was observed during this period. The number of 'debris with lakes' glaciers, the area of debris cover and the size of moraine-dammed lakes has also increased and this could further influence mass loss. Analysis of the climate data indicates that the loss in glacier area is possibly caused by increasing temperatures. However, the reaction of glaciers to climate change is not uniform, as 'clean', 'debris' and 'debris with lakes' glaciers showed variations in area loss, though located in almost the same altitude ranges. Most 'debris-covered glaciers' in Sikkim have moraine-dam lakes at their termini, and showed a greater loss in area than 'clean' glaciers. Though some 'debris-covered glaciers' showed stable fronts, the gradual development and

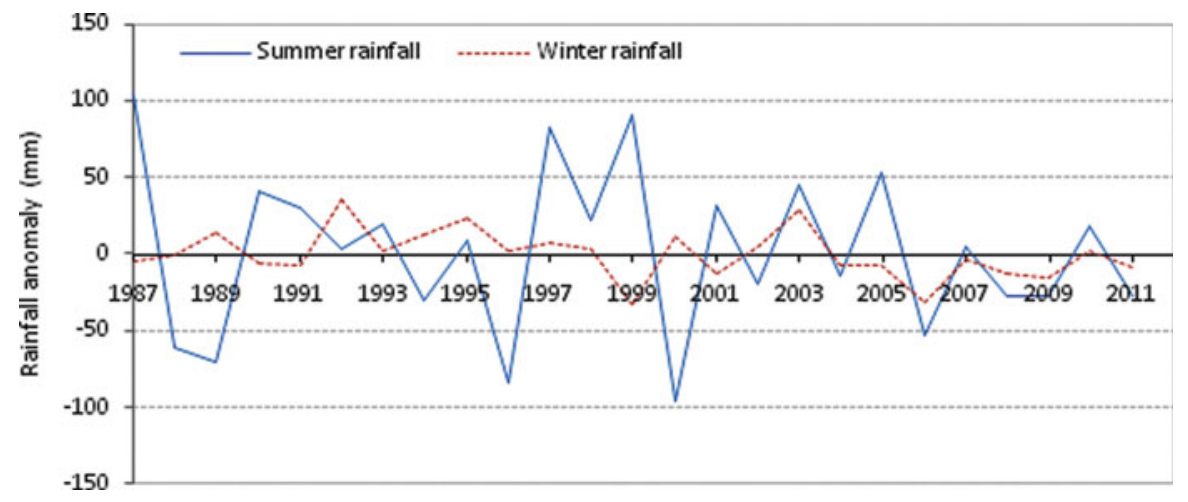

Fig. 12. Variable trends in summer and winter rainfall between 1987 and 2011 at Gangtok. The rainfall data are extracted from the monthly total rainfall records. The summer rainfall is highly variable. 
coalescence of supraglacial lakes led to the formation of moraine-dam lakes at the terminus. This study suggests that 'debris cover' on glaciers can enhance the development of glacial lakes. As a consequence, the retreat of debriscovered glaciers associated with lakes is clearly higher than that of debris-free glaciers.

\section{ACKNOWLEDGEMENTS}

We gratefully acknowledge funding from the Divecha Centre for Climate Change, Indian Institute of Science, Bangalore. We thank two anonymous reviewers for helpful comments. T. Bolch acknowledges funding through Deutsche Forschungsgemeinschaft (DFG). The mean monthly temperature and precipitation data from 1987 to 2011, of Gangtok station were procured from the India Meteorological Department.

\section{REFERENCES}

Bahuguna IM, Kulkarni AV, Arrawatia ML and Shresta DG (2001) Glacier atlas of Tista basin (Sikkim Himalaya). (SAC/RESA) MWRG-GLI/SN/16/2001) Space Application Centre, Ahmedabad

Bajracharya SR and Mool P (2009) Glaciers, glacial lakes and glacial lake outburst floods in the Mount Everest region, Nepal. Ann. Glaciol., 50(53), 81-86 (doi: 10.3189/172756410790595895)

Basnett S and Kulkarni AV eds. (2012) Monitoring the seasonal snow cover in Sikkim Himalaya using remote sensing techniques. In Arrawatia ML and Tambe $\mathrm{S}$ eds. Climate change in Sikkim: patterns, impacts and initiatives. Information and Public Relations Department, Government of Sikkim, Gangtok, 69-80

Basnett S, Kulkarni AV, Rathore BP, Arrawatia ML and Shrestha DG (2011) Monitoring Sikkim Himalayan cryosphere. In Shrestha B and Bajracharya B eds. International Symposium on Benefiting from Earth Observation: Bridging the Data Gap for Adaptation to Climate Change in the Hindu Kush-Himalayan Region, 46 October 2010, Kathmandu, Nepal. International Centre for Integrated Mountain Development, Kathmandu http://geoportal. icimod.org/symposium2010/PPT/Theme-II/smiriti.pdf

Benn DI and 9 others (2012) Response of debris-covered glaciers in the Mount Everest region to recent warming, and implications for outburst flood hazards. Earth-Sci. Rev., 114(1-2), 156-174 (doi: 10.1016/j.earscirev.2012.03.008)

Bennett MR and Glasser NF (2009) Glacial geology: ice sheets and landforms, 2nd edn. Wiley-Blackwell, Chichester

Bhambri R and Bolch T (2009) Glacier mapping: a review with special reference to the Indian Himalayas. Progr. Phys. Geogr., 33(5), 672-704 (doi: 10.1177/0309133309348112)

Bhambri R, Bolch T, Chaujar RK and Kulshreshtha SC (2011) Glacier changes in the Garwal Himalaya, India, from 1968 to 2006 based on remote sensing. J. Glaciol., 57(203), 543-556 (doi: 10.3189/002214311796905604)

Bhambri R, Bolch T, Kawishwar P, Dobhal DP, Srivastrava D and Pratap B (2013) Heterogeneity in glacier response in the upper Shyok valley, northeast Karakoram. Cryosphere, 7, 1385-1398 (doi: 10.5194/tc-7-1385-2013)

Bolch T, Buchroithner M, Pieczonka T and Kunert A (2008) Planimetric and volumetric glacier changes in the Khumbu Himal, Nepal, since 1962 using Corona, Landsat TM and ASTER data. J. Glaciol., 54(187), 592-600 (doi: 10.3189/ 002214308786570782)

Bolch T, Menounos B and Wheate R (2010) Landsat-based inventory of glaciers in western Canada, 1985-2005. Remote Sens. Environ., 114(1), 127-137 (doi: 10.1016/j.rse.2009.08.015)

Bolch T, Pieczonka T and Benn DI (2011) Multi-decadal mass loss of glaciers in the Everest area (Nepal Himalaya) derived from stereo imagery. Cryosphere, 5(2), 349-358 (doi: 10.5194/tc-5349-2011)
Bolch T and 10 others (2012) The state and fate of Himalayan glaciers. Science, 336(6079), 310-314 (doi: 10.1126/science. 1215828)

Bookhagen B and Burbank DW (2010) Toward a complete Himalayan hydrological budget: spatiotemporal distribution of snowmelt and rainfall and their impact on river discharge. J. Geophys. Res., 115(F3), F03019 (doi: 10.1029/2009JF001426)

DeBeer CM and Sharp MJ (2007) Recent changes in glacier area and volume within the southern Canadian Cordillera. Ann. Glaciol., 46, 215-221 (doi: 10.3189/172756407782871710)

Finsterwalder R (1935) On the map of the Zemu Glacier. Himalayan J., 7, 125-138

Fujita K (2008) Effect of precipitation seasonality on climatic sensitivity of glacier mass balance. Earth Planet. Sci. Lett., 276(1-2), 14-19 (doi: 10.1016/j.epsl.2008.08.028)

Fujita K, Sakai A, Nuimura T, Yamaguchi S and Sharma RR (2009) Recent changes in Imja Glacial Lake and its damming moraine in the Nepal Himalaya revealed by in situ surveys and multitemporal ASTER imagery. Environ. Res. Lett., 4, 045205 (doi: 10.1088/1748-9326/4/4/045205)

Gardelle J, Arnaud Y and Berthier E (2011) Contrasted evolution of glacial lakes along the Hindu Kush Himalaya mountain range between 1990 and 2009. Global Planet. Change, 75(1-2), 47-55 (doi: 10.1016/j.gloplacha.2010.10.003)

Granshaw FD and Fountain AG (2006) Glacier change (19581998) in the North Cascades National Park Complex, Washington, USA. J. Glaciol., 52(177), 251-256 (doi: 10.3189/172756506781828782)

Gulley J and Benn DI (2007) Structural control of englacial drainage systems in Himalayan debris-covered glaciers. J. Glaciol., 53(182), 399-412 (doi: 10.3189/002214307783258378)

Immerzeel WW, Van Beeke LPH and Bierkens MFP (2010) Climate change will affect the Asian water towers. Science, 328(5984), 1382-1385 (doi: 10.1126/science.1183188)

Kääb A, Berthier E, Nuth C, Gardelle J and Arnaud Y (2012) Contrasting patterns of early twenty-first-century glacier mass change in the Himalayas. Nature, 488(7412), 495-498 (doi: 10.1038/nature11324)

Kamp U, Byrne M and Bolch T (2011) Glacier fluctuations between 1975 and 2008 in the Greater Himalaya Range of Zanskar, southern Ladakh. J. Mt. Sci., 8(3), 374-389 (doi: 10.1007/ s11629-011-2007-9)

Kaser G, Grosshauser M and Marzeion B (2010) Contribution potential of glaciers to water availability in different climate regimes. Proc. Natl Acad. Sci. USA (PNAS), 107(47), 20 223-20227 (doi: 10.1073/pnas.1008162107)

Komori J (2008) Recent expansions of glacial lakes in the Bhutan Himalayas. Quat. Int., 184(1), 177-186 (doi: 10.1016/ j.quaint.2007.09.012)

Krishna AP (2005) Snow and glacier cover assessment in the high mountains of Sikkim Himalaya. Hydrol. Process., 19(12), 2375-2383 (doi: 10.1002/hyp.5890)

Kulkarni AV (1991) Glacier inventory in Himachal Pradesh using satellite data. J. Indian Soc. Remote Sens., 19(3), 195-203

Kulkarni AV and Alex S (2003) Estimation of recent glacial variations in Baspa basin using remote sensing technique. J. Indian Soc. Remote Sens., 31(2), 81-90 (doi: 10.1007/ BF03030775)

Kulkarni AV, Singh SK, Mathur P and Mishra VD (2006) Algorithm to monitor snow cover using AWiFS data of RESOURCESAT-1 for the Himalayan region. Int. J. Remote Sens., 27(12), 2449-2457

Kulkarni AV, Rathore BP, Singh SK and Bahuguna IM (2011) Understanding changes in the Himalayan cryosphere using remote sensing techniques. Int. J. Remote Sens., 32(3), 601-615 (doi: 10.1080/01431161.2010.517802)

Meier MF (1961) Distribution and variations of glaciers in the United States exclusive of Alaska. IASH Publ. 54 (General Assembly of Helsinki 1960 - Snow and Ice), 420-429 
Nainwal HC, Negi BDS, Chaudhary M, Sajwan KS and Gaurav A (2008) Temporal changes in rate of recession: evidence from Satopanth and Bhagirath Kharak glaciers, Uttarakhand, using Total Station Survey. Current Sci., 94(5), 653-660

Nijampurkar VN (1985) Basal flow rate of Changme-Khangpu glacier, Sikkim Himalaya based on ${ }^{32} \mathrm{Si}$ and ${ }^{210} \mathrm{~Pb}$ chronology. Proc. Indian Acad. Sci., Sect. A, 94(2), 83-89 (doi: 10.1007/ BF02871940)

Nijampurkar VN, Bhandari N, Borole DV and Bhattacharya U (1985) Radiometric chronology of Changme-Khangpu Glacier, Sikkim. J. Glaciol., 31(107), 28-33

Nuimura T, Fujita K, Yamaguchi S and Sharma RR (2012) Elevation changes of glaciers revealed by multitemporal digital elevation models calibrated by GPS survey in the Khumbu region, Nepal Himalayas, 1992-2008. J. Glaciol., 58(210), 648-656 (doi: 10.3189/2012JoG11J061)

Paul F, Kääb A, Maisch M, Kellenberger T and Haeberli W (2004) Rapid disintegration of Alpine glaciers observed with satellite data. Geophys. Res. Lett., 31(21), L21402 (doi: 10.1029/ 2004GL020816)

Paul F and 19 others (2013) On the accuracy of glacier outlines derived from remote-sensing data. Ann. Glaciol., 54(63 Pt 1), 171-182 (doi: 10.3189/2013AoG63A296)

Racoviteanu AE, Arnaud Y, Williams MW and Ordoñez J (2008a) Decadal changes in glacier parameters in the Cordillera Blanca, Peru, derived from remote sensing. J. Glaciol., 54(186), 499-510

Racoviteanu AE, Williams MW and Barry RG (2008b) Optical remote sensing of glacier characteristics: a review with focus on the Himalaya. Sensors, 8(5), 3355-3383 (doi: 10.3390/ s8053355)

Raina VK (2009) Himalayan glaciers: a state-of-art review of glacial studies, glacial retreat and climate change. (SPPI Reprint Series, MoEF Discussion Paper) Ministry of Environment \& Forests, Government of India/G.B. Pant Institute of Himalayan Environment and Development, New Delhi/Kosi-Katarmal, Almora http://www.indiaenvironmentportal.org.in/reports-documents/ himalayan-glaciers-state-art-review-glacial-studies-glacialretreat-and-climate

Raina VK, Bhattachorya V and Pattnaik S (1973) 'Zemu glacier'. Rec. Geol. Surv. India, 105(2), 95-106

Raj BKG, Kumar VK and Remya SN (2012) Remote sensing-based inventory of glacial lakes in Sikkim Himalaya: semi-automated approach using satellite data. Geomat. Natur. Hazards Risk, 4(3), 241-253 (doi: 10.1080/19475705.2012.707153)

Röhl K (2008) Characteristics and evolution of supraglacial ponds on debris-covered Tasman Glacier, New Zealand. J. Glaciol., 54(188), 867-880 (doi: 10.3189/002214308787779861)
Sakai A and Fujita K (2010) Correspondence. Formation conditions of supraglacial lakes on debris-covered glaciers in the Himalaya. J. Glaciol., 56(195), 177-181 (doi: 10.3189/ 002214310791190785)

Sakai A, Takeuchi N, Fujita K and Nakawo M (2000) Role of supraglacial ponds in the ablation process of a debris-covered glacier in the Nepal Himalayas. IAHS Publ. 264 (Symposium at Seattle 2000 - Debris-Covered Glaciers), 119-130

Sakai A, Nishimura K, Kadota T and Takeuchi N (2009) Onset of calving at supraglacial lakes on debris-covered glaciers of the Nepal Himalaya. J. Glaciol., 55(193), 909-917 (doi: 10.3189/ 002214309790152555)

Scherler D, Bookhagen B and Strecker MR (2011) Spatially variable response of Himalayan glaciers to climate change affected by debris cover. Nature Geosci., 4(3), 156-159 (doi: 10.1038/ ngeo1068)

Shrestha AB, Wake CP, Dibb JE and Mayewski PA (2000) Precipitation fluctuations in the Nepal Himalaya and its vicinity and relationship with some large scale climatological parameters. Int. J. Climatol., 20(3), 317-327

Shukla PN, Bhandari N, Nijampurkar VN, Rao DK, Puri VMK and Sharma $S$ (1983) Ice accumulation rate in Changme Khangpu glacier, Sikkim. Proc. Indian Acad. Sci., Sect. A, 92(3), 255-260 (doi: 10.1007/BF02854594)

Tangborn W and Rana B (2000) Mass balance and runoff of the partially debris-covered Langtang Glacier, Nepal. IAHS Publ. 264 (Symposium at Seattle 2000 - Debris-Covered Glaciers), 99-108

UNESCO/International Association of Scientific Hydrology (IASH) (1970) Perennial ice and snow masses: a guide for compilation and assemblage of data for a world inventory, ed. Müller F. (Technical Papers in Hydrology 1) UNESCO/IASH, Paris

Venkatesh TN, Kulkarni AV and Srinivasan J (2011) Relative effect of slope and equilibrium line altitude on the retreat of Himalayan glaciers. Cryos. Discuss., 5(5), 2571-2604 (doi: 10.5194/tcd-52571-2011)

Watanabe T, Lamsal D and Ives JD (2009) Evaluating the growth characteristics of a glacial lake and its degree of danger of outburst flooding: Imja Glacier, Khumbu Himal, Nepal. Nor. Geogr. Tidsskr., 63(4), 255-267 (doi: 10.1080/ 00291950903368367)

Xin W, Liu S, Guo W and Xu J (2008) Assessment and simulaton of glacier lake outburst floods for Longbasaba and Pida Lakes, China. Mt. Res. Dev., 28(3), 310-317 (doi: 10.1659/mrd.0894)

MS received 10 August 2012 and accepted in revised form 15 August 2013 